\title{
Features of Legal Support of Space Activities in Ukraine
}

\author{
Dmytro Zhuravlov
}

Doctor of Law, Professor. First Deputy Director of the Institute of Law and Postgraduate

Education of the Ministry of Justice of Ukraine (Kyiv, Ukraine)

E-mail: ndz0909@gmail.com

https://orcid.org/0000-0002-2045-9631

\begin{abstract}
Andrii Halunko
Ph. D. in Law. Inspector of the public order department of the DPA HNPU in Kherson region (Kherson, Ukraine)

E-mail: armiaandi@ukr.net

https://orcid.org/0000-0002-1842-2506

In the article, the authors reveal the historical and legal aspects of space activities in Ukraine. The historical and legal acts of the Ukrainian SSR and the Soviet Union, regulating the space industry, are analyzed. Considerable attention was paid to the peculiarities of legal regulation of the activities of the main space design bureaus of the time. It is concluded that the space activities of the USSR - in general and the Ukrainian SSR were provided on the basis of sublegislative normative legal acts (resolutions of the Council of Ministers and orders of the Central bodies of the Communist party). However, the lack of the national space law was offset by systematic and full funding of space activities, resulting in the Soviet Union having a powerful space industry. In the conditions of modern development, Ukraine has all the opportunities to achieve significant development of the space industry, using the positive experience of the USSR and opening access to space activities of private investment.

Keywords: space activities, law, space law, space technologies, private investments, Soviet regime, launch vehicles
\end{abstract}

Received: September 11, 2019; accepted: October 07, 2019

Advanced Space Law, Volume 4, 2019: 116-124.

https://doi.org/10.29202/as1/2019/4/11

(C) Zhuravlov, Dmytro, 2019.

(C) Halunko, Andrii, 2019 


\section{Introduction}

Now, when new changes in the space law of Ukraine allowed private individuals to develop, manufacture and launch spacecraft, once a powerful space power has a chance to increase its contribution to the world's space technology through private investment.

The space industry of Ukraine has its glorious history and legal specifics of origin and development in the depths of the Soviet regime. In the article the authors revealed the historical and legal features of the origin and development of the space industry of Ukraine. There is a certain literature on these issues, which, however, in most cases does not disclose the analyzed problems. After all, scientists have focused on the technical and historical factors of the development of the space industry in Ukraine. They hardly analyzed the legal issues.

Scientific novelty: firstly, it is proved that Soviet Ukraine, which was under the totalitarian control of Moscow, did not have a high level of legislation (laws) regulation of the space industry was carried out on the basis of sublegislative normative and administrative legal acts of the ruling party and government; secondly, the space industry had funding in full; thirdly, the space industry of Ukraine, after independence, had certain scientific and technological successes, but due to the legislative ban to attract private investment in this industry led to its decline.

First, in the article we will reveal the phenomenon of how the Soviet regime managed to create high space technologies in the conditions of poverty of citizens, systemic violation of human rights. We will then focus on the specifics of the international legal regulation of the exploration and use of outer space. Significant attention in the article will be paid to the specifics of the legal regulation of the main space design bureaus and sublegislative nrmative legal regulation of the space industry in the Soviet state. The article ends with the disclosure of the modern legal regulation of the space industry in Ukraine.

\section{Human rights violations and high space technologies as a phenomenon of the Soviet past}

In the history of space, an important place belongs to the state, which ceased to exist in 1991 - the USSR. A part of which consisted of Ukrainian lands. Modern Ukraine is the successor of the Ukrainian Soviet Socialist Republic. It, from the point of view of international law, has been recognized since the formation of the UNO. Although the real independence Soviet Ukraine did not have. All important decisions were made in Moscow — the capital of the USSR, and Kyiv - the capital of Soviet Ukraine, implicitly carried them out. After all, after the Holodomor (1932-1933), when the Soviet regime starved more than five million Ukrainians, resistance to the Soviet regime was carried out only by the Ukrainian insurgent army (until 1963) in the Western provinces of Galicia [Natsional'na, 2008]. The population of other regions did not have enough forces for resistance.

However, the Soviet state, although through ruthless exploitation of citizens, has achieved significant success in the development of the space industry and space technologies. Among them there are the first artificial satellite of Earth, the first manned human flight into outer space, the first flyby of Moon, the first artificial objects on the surface of Venus and Mars, etc.

It was a peculiar phenomenon. When in the forties and fifties of the twentieth century, most of the citizens who inhabited the republics of the USSR were starving, and for the military and civilian rocket space industry, the ruling Communist party and the Soviet government, spared 
no expense. The first space programs were carried out according to the rule of actual costs. How much money was spent, the same amount came from the state budget. Practically the estimate was absent. As much money was spent on space, as much it was possible to explore, without restrictions of upper limit.

This led to the fact that the material support of designers, engineers and manufacturers of space technology was high, and even higher was the prestige of working in the space industry. Accordingly, the best engineers and workers sought to get there. And they did, because at that time there was almost no corruption in the Soviet Empire. All this led to the fact that in the space industry worked design, engineering and working elite. Against the background of general impoverishment, these persons lived very well. Although this did not save them from repression.

In the exploration and use of outer space, the Soviet Empire for a long time, along with the United States, had more success. However, in general, this had terrible consequences for the Soviet country. The arms race, including competitions in the field of rocket construction, played a cruel joke with that country. They became one of the significant reasons for the termination of the existence of the Soviet Union.

Although it is undeniable that it was in the depths of that system that the rocket space industry of Ukraine was created, international space law was established, and separate elements of national space law were initiated. The system of space legal norms of Ukraine designed to regulate space activities of today was born in the last twentieth century [Malkov, 2001].

\section{Ukraine and international-legal regulation of the exploration and use of outer space}

Space rules can be objectively divided into international and national norms of space law. Although during the entry of Ukrainian lands into the Soviet Empire, the second ones only conditionally can be called the norms of space law. After all, they were based on sublegislative normative legal and administrative acts of the Soviet government, secret instructions of the ruling Communist party at the time and regulatory and administrative orders of the Minister of defense and other special ministries of that country.

As for international space law, Ukraine, as an integral part of the Soviet system at that time, fully adhered to the international space treaties signed and ratified by the Soviet Union. In today's conditions, Ukraine continues to comply with them, because it is the successor of the rights and obligations under international treaties of the USSR, which do not contradict the Constitution and national interests. [Pro pravonastupnytstvo, 1991].

Based on these positions, the space treaties that Ukraine adheres to include:

- The Treaty on the principles of the activities of States in the exploration and use of outer space, including Moon and other celestial bodies of 1967, which the USSR ratified by the decree of the Presidium of the Supreme Soviet of the USSR of June 18,1967 . The Treaty entered into force for the USSR including Ukraine on October 10,1967;

- The agreement on the rescue of cosmonauts, the return of cosmonauts and the return of objects launched into outer space in 1968, the USSR ratified it by the decree of the Presidium of the Supreme Soviet of the USSR from September 17, 1968. The agreement entered into force for the USSR, including for Ukraine on December 03, 1968 ; 
- Convention on international responsibility for damage caused to space objects, 1972;

- Convention on registration of objects launched into outer space, 1976.

So, Ukraine from the moment of ratification of the USSR to the present day fully adheres to the norms of the fundamental international space treaties, as the successor of the rights and obligations under international treaties, since they do not contradict the Constitution and the interests of Ukraine. These international treaties contain the norms of international space law.

\section{Leading designers of rocket technology of the Soviet state and legal regulation of special design bureaus which they headed}

The most famous Soviet designer of rocket technology is Sergei Korolev (1907-1966). He was born, raised and educated in Ukraine. However, the development of its first missiles began in Moscow in 1931. From 1938 to 1944 he was repressed by the Soviet regime. Since September 1945, he resumed activities in the field of rocket science. In 1950, he passed on combat duty for the armed forces of the Soviet state rocket R1 (analogue of the German V-2). After that, by order of the government of the Soviet state on April 24, 1950, a special space design Bureau № 1 (Research Institute 88) was created, and Sergei Korolev was appointed as its chief designer. In 1956, under his leadership, a two-stage Intercontinental ballistic missile R7 with a head mass of 7 tons and a flight range of 8000 kilometers was created. However, Sergey Korolev achieved the greatest success not in the military, but in the peaceful segment of space launches. He added the third and fourth stages to the combat rocket, which made it possible to launch the first artificial earth satellite on October 4, 1957 and open the space age of mankind. And on April 12, 1961, he again surprised the world community. He conducted the first manned flight of a spacecraft with cosmonaut Yuri Gagarin on board [Mozharovs'ka, 2019].

Valentin Glushko (1908-1989), was born in Odessa, Ukraine. He is the founder of the Soviet liquid rocket engines. His engines RD107 and RD108 stood on the first Soviet Intercontinental missile R7. It was on his engines fly rockets Sergey Korolev. They put into orbit the first artificial satellite and sent the first human into space, etc. He began his professional career in the development of rocket engines in 1929. In 1930, under his leadership, the first Soviet liquid-propellant rocket engine was created. From 1938 to 1944 he was repressed by the Soviet regime. Valentin Glushko created more than 50 types of rocket engines. His rocket engines R253 stood on the carriers "Proton" and "Soyuz". Since 1974, he became the General designer of the research and production Association "Energia" It was for the needs of this reusable space system that the most powerful rocket engine RD170 was created [Akademik, 2019].

Mikhail Yangel (1911-1971), was born in Irkutsk province, Russian Empire, in a family of ethnic Ukrainians. Since April 1954, chief designer of special design Bureau №. 586 in Dnipro, Ukraine [Dovhal', 2011]. He was a doctor of science, academician of the Academy of Sciences of Ukraine. His design office carried out the development of a new choice 8K63, missile on high boiling fuel components with an autonomous control system, known as R-12. In June 1957, the first and successful test of the medium-range missile R-12 (NATO classification SS4) was carried out [Gorbulin, 2011].

On the basis of this rocket, a light-class carrier rocket with the name "Cosmos" was created. It launched spacecraft weighing up to 450 kilograms into an orbit of up to 200 kilometers, from the Kapustin-Yar and Plesetsk cosmodromes. A total of 165 launches were carried out, of 
which 143 were successful. Thus, Mikhail Yangel, founded a new direction in Soviet rocket science on new fuel components with an Autonomous control system.

In addition, he founded a research and design school, the result of the activities of which were significant successes of pupils of the space construction master, in particular, the Design Office "Yuzhnoye" has created a carrier rocket Zenit 3SL, which with great accuracy puts into orbit a payload of 13740 kilograms [Biographies, 2019].

Vladimir Chelomey, (1914-1984), was born on June 30, 1914 in Siedlec, Poland. Soon his family moved to Kyiv, where he received secondary and higher engineering education. During World War II, he was Director and chief designer of plant № 51, where he developed aircraft shells (an analogue of the German V-1). In 1955, a special design Bureau-52 was created, the chief designer of which became Vladimir Chelomey. There cruise missiles were created, the wings of which — for the first time in the world — opened in flight. He was also the first to introduce the mortar launch of ballistic missiles from containers. Developed under his leadership, the UR-500 proton launch vehicle can put satellites weighing up to 22 tons into orbit, and stations weighing more than 5 tons on interplanetary routes [Gorbulin, 2014].

Alexander Nadiradze (1914-1987), was born in Georgia. He was the chief designer of mobile intercontinental complexes with solid-fuel ballistic missiles. In the Soviet classification "Pioneer" 15P645K with a missile 15ZH45 (RSD-10), in the Western classification SS20. He died on September 3, 1987, and on December 8 this same year presidents of the US Ronald Reagan and of the USSR Mikhail Gorbachev signed Treaty about eliminating of average and a lesser range missiles, that led to full destruction of all missiles — "Pioneer" created by designer Alexander Nadiradze [Dohovir, 1987; Pro realizatsiyu, 1994]. Although created during his lifetime Topol RS-12M (15P158) missile system was successfully adopted by the strategic missile forces of the armed forces of the Soviet Union after the death of the chief designer on December 1, 1988. Its development began in 1977 in accordance with the Resolution of the Council of Ministers of the Soviet state № 212. This complex is armed with a three-stage solid-propellant intercontinental ballistic missile 15ZH58 in the NATO SS22 classification. The maximum range of the missile is $11,000 \mathrm{~km}$ [RS 12M, 2019].

Consequently, the vast majority of the leading designers of rocket technology in the Soviet era were of Ukrainian origin. It was thanks to them (Sergei Korolev, Valentinin Glushko, Mikhail Yangel, Vladimir Chelomey) that the majority of launch vehicles were created, both for the military and for peaceful space. The first satellite and the first man were launched into outer space, the orbital stations reached Moon, Venus, Mars, etc. The legal activities of the special design bureaus, which they headed, were regulated by the common sublegislative normative legal acts of the Communist party and the government. A significant part of these designers were illegally repressed by the Soviet regime.

\section{Sublegislative normative legal regulation of the space industry in the Soviet country and the role of design bureaus and enterprises located in Ukraine in this process}

As noted above, the Soviet state did not create a single national space law. All legal regulation as for the development, construction, testing and operation of missile technology was carried out on the basis of sublegislative normative legal and regulations and administrative acts.

The beginning of such regulation practically became the top secret resolution of the Council of Ministers of the Soviet state of May 13, 1946 № 1017-419 “About questions of jet weapons”. 
The document provided the establishment of a special Committee on jet technology under the Council of Ministers, as well as research institutes, design bureaus and testing grounds on this topic. These included the special Design Bureau of the Research Institute № 88, at which in August of the same year the Department № 3 was formed for the development of long-range ballistic missiles under the leadership of Sergei Korolev, which eventually became the special Design Bureau № 1 (OKB1) [Baturin, 2017].

In Ukraine, on the basis of an administrative act, which was implemented through the order of the Minister of the armed forces of the Soviet state, the machine-Building plant № 586 in the city of Dnipro, was reorganized on May 10, 1952 into the southern machine-building plant № 586. At this plant, mass production of combat strategic missiles was started. There in the city of Dnipro, in April, 1954 the Special design Bureau № 586 - future design "Southern" Bureau was formed. And after 5 years of their joint development - medium-range rocket R-12 on high boiling fuel was adopted by the Armed forces of the Soviet state [The Legend, 2013]. In 1962, the first Ukrainian satellite Kosmos-1 was put into orbit by the carrier rocket 63S1 Kosmos, and in 1980 flight tests of the heavy carrier rocket Cyclone-3 were completed. However, the main segment of the design and production of missile technology in Ukraine in that era were military orders.

Over time, OKB-1 under the leadership of chief designer Sergei Korolev was tasked to develop several types of spacecrafts. On May 22, 1959, Resolution № 264 of the Council of Ministers "on the preparation of man for space flights" was issued. In it the deadlines of conducting of first selection into the team of Soviet cosmonauts were defined, and also performers and order of works on creating experimental ship-sattelite, which should become the basis for the development of manned ship for man flights into space [Zheleznyakov and all, 2002]. December 10, 1959 the resolution of the Council of Ministers of the USSR № 618 "On the creation of automatic interplanetary stations for landing on Moon, flights to Venus and Mars" was adopted.

Further, on June 4, 1960, the Council of Ministers issued Resolution № 238 “On the implementation of the plan for the exploration of outer space for 1960 and the 1st half of 1961". On June 23, 1960, the Council of Ministers issued Resolution № 296 "On the creation of powerful launch vehicles, satellites, spaceships and the exploration of outer space in 19601967". In this resolution, the first attempt was made at the highest level to approve the program for the development of Soviet cosmonautics in the form of a seven-year plan. In 1962, work began on the design of the Soyuz rocket and space complex for a manned flyby of Moon. These works were legalized by the resolutions of the Council of Ministers № 160 of April 16, 1962 and № 435 of December 3, 1963, on September 24, 1962, the Resolution "On further exploration of Moon" was issued. It fixes the decision to land a Soviet cosmonaut on Moon [Malkov, 2001].

In addition to the program for the development of Moon, the Soviet state worked out projects of manned flights to the nearest planets: Mars and Venus. Implementation of these projects in some cases was carried out according to the orders of special ministries. So on July 30, 1969 the Minister of the Ministry of General mechanical engineering signed the order № 232 "About development of a rocket and space complex that provides expedition to Mars" [Malkov, 2001].

In the second half of the 70-ies of the XX century, space activities for the exploration of space and celestial bodies in the Soviet country began to be carried out not as intensively as before. In connection with the desire to restore and enhance the activities on space research, 
Solar system planets, their satellites the Commission of the Presidium of the Council of Ministers on military-industrial issues adopted on 1 August 1983 resolution № 274 “On the development of unmanned spacecraft to study planets of the Solar system, Moon and outer space". According to it, it was entrusted to conduct the research and development work on the creation of a mobile device for the study of the Mars satellite-Phobos [Malkov, 2001].

Consequently, the legal regulation of the space industry in the Soviet state was carried out on the basis of sublegislative norms and administrative acts of the Soviet government and ministries, primarily the Ministry of defense. The special design Bureau № 586 (the future Pivdenne design Bureau) and the southern machine-building plant № 586 were established by normative and administrative acts. They specialized in the design and manufacture of mediumrange liquid-propellant military missiles and light-class launch vehicles to launch satellites into low-earth orbits on high-boiling fuel. Subsequently, the designers and missile manufactures mastered military ballistic missiles of heavy class, which after their removal from service were used as launch vehicles to launch satellites.

\section{Legal regulation of the space industry in Ukraine in the first years of independence of Ukraine}

Ukraine as a state became independent in 1991. All spheres of public life, including the legal regulation of the production and launch of launch vehicles and satellites at the level of international space law began to be regulated also by domestic legislation. During the first decades of independence, more than 150 launch vehicles and 375 spacecrafts were launched into space. One of the greatest space achievements of Ukraine was the creation of powerful spacecraft and launch vehicles. For example, such satellites for remote sensing of the earth as "Sich", carrier rockets "Dnipro" and "Zenit-3SL", as well as "Cyclone-3". On August 1, 1995, the first Ukrainian artificial research satellite "Sich-1" was launched into low-earth orbit. And the launch was carried out with the help of the Ukrainian carrier rocket "Cyclone-3" [Ishchenko, 2018].

In 1996, the first Law of Ukraine "Aboutn space activities" came into force, which defines that space activities are scientific space research related to the creation and application of space technology, the use of outer space. State regulation and management in the sphere of space activity in Ukraine are carried out by legislative establishment of the basic principles, norms and rules of space activity, introduction of licensing of such activity, etc. [Pro kosmichnu, 1996]. The main drawback of this law was that the creation, launch and operation of space equipment could be handled exclusively by government agencies and enterprises. This led to the fact that the space industry of Ukraine did not receive private investment, as a consequence — to its decline. So the state budget totally lacked funds for the implementation of space programs. Only on October 2, 2019 it was corrected according to the Law of Ukraine №143-IX “About modification of some laws of Ukraine concerning the state regulation of space activity" [Pro vnesennya zmin, 2019]. In which it is specified that scientific researches, development, production, operation, ensuring start-up and return of space vehicles can be carried out by the establishments and the organizations of any form of ownership and organizational-legal form. This opens up significant opportunities for private investors to use the space potential that is available in Ukraine.

Thus, the new national space law provides the space industry of Ukraine with a new chance for development through private investment. 


\section{Conclusions}

When analyzing the history of space activities, the current situation and forecasting the future of the space state, the world community and all our civilization on Earth and beyond, the prospects of space humanity, we deal with complex conceptual, legal, socioenvironmental, digital and other models of the past, present and future. The adequacy and reliability of promising models of the space activities and the cosmic future of humanity raise doubts in comparison with the complex real global socio-political processes, trends and threats to human life on Earth in the 21st century [Krichevsky \& Udartsev, $2019: 31$ ].

In the article we have revealed the historical and legal aspects of the heyday and decline of the space industry of Ukraine when it became part of the Soviet state and in the first years of independence. The issues of the phenomenon of space technology in the Soviet Ukraine, features of the international legal and national regulation of research and use of outer space at the time were clarified. The authors stressed that the new space law of Ukraine (2019), provides significant opportunities for private investors. In the following articles we will pay more attention to the latest national space legislation of Ukraine.

\section{References}

Akademik Valentyn Petrovych Hlushko. Department of Lunar and Planetary Researcher, 2019. http://selena.sai.msu.ru/Home/Resear/Glushko/glushko.htm

Baturin, Yuri. The Birth of Russian Rocket and Space Industry. Rocket and space instrumentation and information systems. 2017, Volume 4, Issue 1, p. 89-97. http://russianspacesystems. ru/wp-content/uploads/2017/04/13_s89.pdf

Biographies Mikhail Yangel. Design Office "Yuzhnoye”. 2019. https://www.yuzhnoye.com/ en/company/history/yangel.html

Dohovir mizh Soyuzom Radyans'kykh Sotsialistychnykh Respublik ta Spoluchenymy Shtatamy Ameryky pro likvidatsiyu yikh raket seredn'oyi dal'nosti $i$ men'shoyi dal'nosti, 08.12.1987. № $840 \_021$ https://zakon.rada.gov.ua/laws/show/840_021

Dovhal', Serhiy. Yoho raketna velychnist'. Ukrayina moloda, 25.10.2011. https://www. umoloda.kiev.ua/number/p-0/?q= $\%$ D1 $\% 80 \%$ D0 $\%$ B0 $\%$ D0 $\%$ BA $\%$ D0 $\%$ B5 $\%$ D $1 \% 82 \%$ D0\%BD $\%$ D0\%B0+\%D0\%B2\%D0\%B5\%D0\%BB\%D0\%B8\%D1\%87\%D0\%BD\%D $1 \% 96 \% \mathrm{D} 1 \% 81 \% \mathrm{D} 1 \% 82 \% \mathrm{D} 1 \% 8 \mathrm{C}$

Gorbulin, Volodymyr. Istorychna osobystist': do 100-richchya vid dnya narodzhennya M. K. Yanhelya. Science And Science of Science, 2011. № 4. pp. 5-15.

Gorbulin, Volodymyr. Through Thorns to Stars. To the 100th Anniversary of Vladimir Chelomei. Space Science and Technology, 2014 № 20; (4). p. 50-63. https://doi. org/10.15407/knit2014.04.050

Ishchenko, Anastasiya. Kosmichna Ukrayina: dosyahnennya i peremohy. Segodnya, 2018. https:// ukr.segodnya.ua/ukraine/kosmicheskaya-ukraina-dostizheniya-i-pobedy-1164738.html

Krichevsky, Sergey and Sergey Udartsev. Space State on Earth and Beyond: Philosophy, Models, Experience and Prospects. Philosophy and Cosmology, Vol. 23. 2019: 30-52. https://doi.org/10.29202/phil-cosm/23/4

Malkov, Sergey. Kosmicheskoye pravo Rossii. Institut vozdushnogo i kosmicheskogo prava, 2001. https://aerohelp.com/sites/default/files/malkov_kosmicheskoe_pravo_rossii_ monografiya.pdf 
Malkov, Sergey. Mezhdunarodnoye kosmicheskoye pravo. SPb.: SPbGUAP, 2002. 344 p.

Mozharovs'ka, Anastysiya, Khto takyy Serhiy Korol'ov: biohrafiya ukrayins'koho inzhenera, yakyy vidpravyv pershu lyudynu v kosmos. 24 Tekhno, 2019. https://24tv.ua/techno/ sergiy_korolov_biografiya_dosyagnennya_golovnogo_konstruktora_kosmichnih_ korabliv_n1040133

Natsional'na knyha pam'yati zhertv Holodomoru 1932-1933 rokiv v Ukrayini. Vydavnytstvo imeni Oleny Telihy, 2008. http://www.memory.gov.ua:8080/ua/508.htm

Pro ratyfikatsiyu Dohovoru mizh Soyuzom Radyans'kykh Sotsialistychnykh Respublik $i$ Spoluchenymy Shtatamy Ameryky pro likvidatsiyu yikhnikh raket seredn'oyi dal'nosti $i$ menshoyi dal'nosti. Ukaz Prezydiyi Verkhovnoyi Rady SRSR vid 28 travnya 1988 roku № 28 https://zakon.rada.gov.ua/laws/show/840_021

Pro pravonastupnytstvo Ukrayiny. Zakon Ukrayiny vid 12.09.1991, № 1543-XII https:// zakon.rada.gov.ua/laws/show/1543-12

Pro realizatsiyu Ukrayinoyu polozhen' Dohovoru mizh SSHA i SRSR pro likvidatsiyu yikh raket seredn'oyi ta menshoyi dal'nosti. Rozporyadzhennya Prezydenta Ukrayiny vid 5 sichnya 1994 r. № 1/94-rp. https://zakon.rada.gov.ua/laws/show/1/94-pп

Pro kosmichnu diyal'nist'. Zakon Ukrayiny vid 15.11.1996, № 502/96-BP. https://zakon.rada. gov.ua/laws/show/502/96-вp

Pro vnesennya zmin do deyakykh zakoniv Ukrayiny shchodo derzhavnoho rehulyuvannya kosmichnoyi diyal'nosti. Zakon Ukrayiny vid 02.10.2019, № 143-IX https://zakon. rada.gov.ua/laws/show/143-ix

RS 12M Topol', raketa RT 2AM/15ZH58 - SS 22 SICKLE. Military Russia, 2019. http:// militaryrussia.ru/blog/topic-600.html

The Legend of Domestic Rocket Designing Extended Session of Coordinating Council for Organizing of Joint Work of Yangel "Yuzhnoye" Design Office and Scientific Institutions of NAS of Ukraine Devoted to $90^{\text {th }}$ Anniversary of Academician V.F. Utkin. Visnyk of the NAS of Ukraine, 2013. № 12. p. 5. http://www.visnyk-nanu.org.ua/en/ node/1204

Ukrayins'ka povstans'ka armiya. Ukrayins'kyy instytutu natsional'noyi pam"yati, 2016. https:// uinp.gov.ua/informaciyni-materialy/viyskovym/ukrayinska-povstanska-armiya

Zheleznyakov, Aleksandr, Vitaliy Lebedev. Letopis' kosmicheskoy ery. 1959 god. SPb.: Izd-vo "Sistema”, 2003. p. 55-56. 